\title{
樹脂被覆紙の表面平滑性の評価
}

\author{
野 田 徹*1 $\cdot$ 椿正 行*2・桐 谷 秀 紀*3
}

\section{Evaluation of Surface Smoothness of Resin Coated Paper}

\begin{abstract}
Noda, Tooru*1/Tsubaki, Masayuki*2/Kiritani, Hideki*3
Resin-coated paper (RC paper) which is manufactured by melt-extrusion of a coating of polyethylene resin onto both sides of the paper base is mainly used as a support for imaging materials such as photographic paper. The surface smoothness of RC paper is an important property and it is necessary to quantitatively define the surface smoothness. We thus analyzed the surface roughness of RC paper and sharp dents (pits) or "pear skin" generated on the surfaces of RC paper. We found that the surface roughness calculated by a flattening estimation using a leveling theory for a liquid coating corresponded well with the experimental values. Also we found that the observed density of surface pits agreed well with those obtained by using an index based on the flattening estimation model where the pits are related to deep vacancies which still remain on the surface of the base paper even after coating the base paper. These results support the validity of the flattening estimation model and the pit generation model where the pits are considered to be projections of the volume of deep vacancies remaining on the surface of the base paper. The pit estimation model can be widely applied by using the index correcting the elastic behavior of a resin.
\end{abstract}

Key words : Resin-coated paper/Base paper/Surface roughness/Pit/Surface vacancy

\section{1. 緒言}

紙基材（以下基紙という）の両面にポリエチレン（PE と表すことがある）を T型ダイスから溶融押し出しコー

*1 三菱製紙(侏総合研究所・生産技術センター

東京都暮飾区東金町 1-4-1（１25-8525）

(現在) 東洋ハトメ工業(侏)

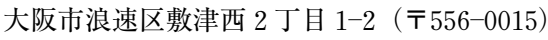

Process Development Laboratories, Corporate Research Center, Mitsubishi Paper Mills Limited. 4-1, Higashikanamachi 1chome, Katsushikaku, Tokyo 125-8525, Japan

(Present Address) Touyou Hatome Kougyou Limited.

1-24, Shikitsunishi 2-chome, Naniwaku, Osaka 556-0015, Japan

*2 三菱製紙(制総合研究所・生産技術センター

東京都葛飾区東金町 1-4-1（ ₹ 125-8525）

Process Development Laboratories, Corporate Research Center, Mitsubishi Paper Mills Limited. 4-1, Higashikanamachi 1chome, Katsushikaku, Tokyo 125-8525, Japan

*3 三菱化学秼科学技術研究センター プロセス生産技術部門 プ ロセスモデリング研究所

横浜市青葉区鴨志田町 1000（テ227-8502）

Process Systems Engineering and Production Technologies Field, Computer-Aided Modeling Simulation Lab, Science and Technology Research Center, Mitsubishi Chemical Corporation. 1000, Kamoshida-cho, Aoba-ku, Yokohama 227-8502, Japan 2003.2.19 受理
ティングして製造されるポリエチレン樹脂被覆紙1,2) (以 下， RC 紙という）は，写真印画紙やインクジェット材料 などの画像材料用支持体として用いられている，その大き な理由は $\mathrm{RC}$ 紙の平滑性が良好なことである.

しかし， $\mathrm{RC}$ 紙の平滑性は，基紙の平滑性，樹脂物性， 溶融押出条件などの色々な要因に左右され, それらの定量 的な要因は明らかでなかった．また， $\mathrm{RC}$ 紙の表面にピッ トあるいは梨地と呼称される鋭い窪みが発生することがあ り，これも表面の平滑性を悪くする大きな要因であった. そこで本報では, 表面粗さの定量的な要因を明らかにし, またピットの発生機構を明らかにして, 表面粗さが小さく, ピットの発生が極めて少ない平面性の良好な $\mathrm{RC}$ 紙の設計 を可能にすることを目的にするものである．特に， RC 紙 の表面粗さとピットの形成の現象をモデル化し, 種々の仮 定の基に予測式を導出し, 導出した式の妥当性を実験結果 と予測結果の比較によって言及することを目的とするもの である。

$$
\text { 2. モ デル }
$$

\section{$2.1 \mathrm{RC}$ 紙の表面粗さを表すモデルの基礎}

基紙面にポリエチレンを $\mathrm{T}$ 型ダイスから溶融押し出し コーティングし，冷却ロールでプレスして RC 紙を製造す 


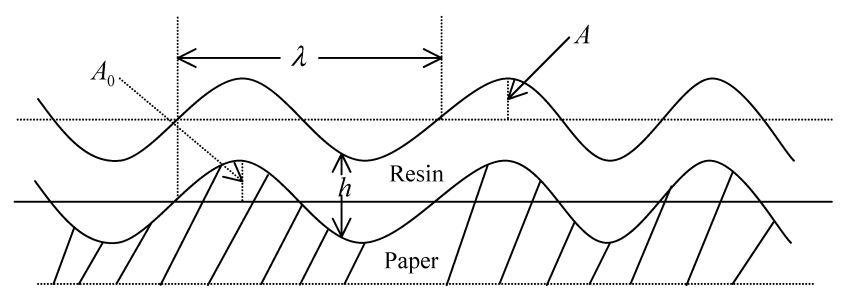

Fig. 1 The flattening model of an RC paper on coating a resin layer onto a base paper

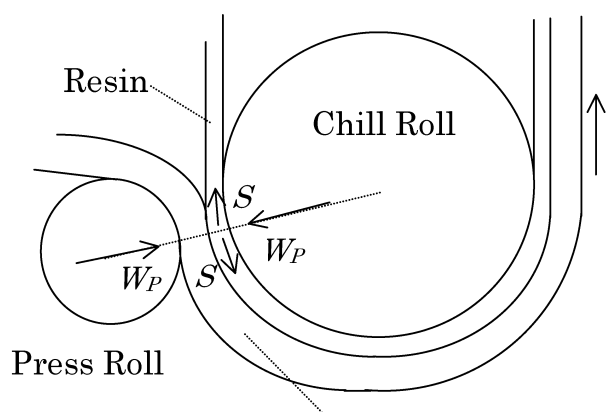

Base Paper

Fig. 2 The thin resin layer receiving a press pressure, $W_{P}(S$ : Press tension $)$

る際のポリエチレン被覆層の平坦化のモデルをコーティン グにおけるレベリングのモデルに置き換えて設定した。そ のモデルを図 1 に示す.

$\operatorname{Orchard}^{3}$ によれば，塗液のレベリングの時間依存性は， 塗液表面の凹凸をサインカーブと見なせば次式で表される。

$$
\ln \left(\frac{A}{A_{0}}\right)=-\frac{\pi}{\lambda} \cdot f\left(\frac{2 \pi h}{\lambda}\right) \int_{0}^{t}\left(\frac{\gamma}{\eta}\right) d t
$$

(ここで, $A_{0}$ : 時間 0 でのサインカーブの振幅, $A$ : 時間 $\mathrm{t}$ でのサインカーブの振幅, $\lambda$ : サインカーブの波長, $h$ : 塗液の平均厚さ, $\gamma$ : 塗液の表面張力, $\eta$ : 塗液の粘度, $f(x)$ は流動関数と呼称される.)

$$
\begin{aligned}
f(x) & =\frac{\tanh (x)-x \operatorname{sech}^{2}(x)}{1+x^{2} \operatorname{sech}(x)} \quad(2) \quad\left(\text { Here, } x=\frac{2 \pi h}{\lambda}\right) \\
& =\frac{\sinh (x) \cosh (x)-x}{\cosh ^{2}(x)+x^{2}}
\end{aligned}
$$

(1)式を溶融押し出しコーティング加工での平坦化に適 用するためには, 表面張力 $\gamma$ をプレス加工でのプレス張 力 $S$ に読み替える必要がある。いま，図 2 に示すように 基紙への樹脂被覆時に樹脂層にはプレス圧力が加わり，プ レス張力 $S^{4)}$ が生ずる. 従って, (1) 式の $\gamma$ をプレス張力 $S$ (4) 式で置き換えればよい.

$$
S=W_{P} R_{P}
$$

（ここに， $W_{P}$ : プレス圧力, $R_{P}$ : プレスロール半径. )

\section{$2.2 \mathrm{RC}$ 紙の表面粗さを表す予測式}

(1) 式において， $A$ を波長 $\lambda$ での $\mathrm{RC}$ 紙の表面粗さ $R_{P y a}$, $A_{0}$ を波長 $\lambda$ での基紙の表面粗さ $R_{P y_{0}}, \gamma$ を時間に無関係
なプレス張力 $S$ と読み替えると，

$$
\ln \left(\frac{R_{P y a}}{R_{P y 0}}\right)=-\frac{\pi}{\lambda} \cdot f\left(\frac{2 \pi h}{\lambda}\right) \int_{0}^{t}\left(\frac{S}{\eta}\right) d t
$$

(ここで， $R_{P y a}$ : 波長 $\lambda$ での $\mathrm{RC}$ 紙の表面粗さ， $R_{P y 0}$ : 波長 $\lambda$ での基紙の表面粗さ.)

となる. 冷却ロールでのプレス加工中の冷却過程について， プレス時間が $10 \mathrm{~ms}$ 以下（プレススケールによる発色長 さと基紙走行速度より算出）の相当短い時間であるため, 樹脂温度 $T_{0}$ と冷却ロール温度 $T_{f}$ との温度差 $\left(T_{0}-T_{f}\right)$ に 比例し, 樹脂厚さ $h$ に反比例すると考えられるので, 冷 却速度は樹脂層内の平均温度を $T$ として次式で与えられ ると仮定する。

$$
\frac{d Q}{d t}=\rho C A_{s} h \frac{d T}{d t}=-k_{c o n} A_{s} \frac{T_{0}-T_{f}}{h}
$$

(ここに, $\mathrm{Q}$ : 熱量, $\mathrm{t}$ : 時間, $\rho: \mathrm{PE}$ 樹脂の密度, $\mathrm{C}: \mathrm{PE}$ 樹脂の熱含量, $A_{s}$ : 面積, $k_{c o n}: \mathrm{PE}$ 樹脂の熱伝導率.)

ゆえに, 樹脂層内の平均温度 T は下式で与えられる。

$$
\begin{aligned}
T & =T_{0}-\alpha\left(T_{0}-T_{f}\right) t \quad(7) \quad\left(\text { Here, } \alpha=\frac{k_{c o n}}{\rho C h^{2}}\right. \\
& =T_{0}-\frac{k^{\prime} t}{h^{2}} \quad \text { (9) } \quad\left(\text { Here, } k^{\prime}=\frac{k_{c o n}\left(T_{0}-T_{f}\right)}{\rho C}\right.
\end{aligned}
$$

一方, 樹脂粘度 $\eta$ の温度依存性は下式 ${ }^{5)}$ の指数関数で与 えられる。

$$
\begin{aligned}
& \eta=a e^{-b T}=a e^{-b\left(T_{0}-k^{\prime} t / h^{2}\right)}=a e^{-b T_{0}} \cdot e^{b k^{\prime} t / h^{2}} \\
&(こ こ に, a, b=\text { 定数. })
\end{aligned}
$$

したがって，

$$
\eta(t)=c \exp \left(\beta t / h^{2}\right)
$$

$$
\text { Here, } \beta=b k^{\prime}=\frac{b k_{c o n}\left(T_{0}-T_{f}\right)}{\rho C}
$$

であり, $c=\eta(0)=\eta_{0}$ とおくと, 下式が得られる.

$$
\eta(t)=\eta_{0} \exp \left(\beta t / h^{2}\right)
$$

故に, 時間 0 から時間 $t_{m}$ までの $1 / \eta$ の積分は, 下式で 与えられる。

$\int_{0}^{t_{m}} \frac{1}{\eta} d t=\int_{0}^{t_{m}} \frac{1}{\eta_{0} e^{\beta t / h^{2}}} d t=\frac{1}{\eta_{0}} \int_{0}^{t_{m}} e^{-\frac{\beta}{h^{2}} t} d t$

$=\frac{1}{\eta_{0}}\left(-\frac{h^{2}}{\beta}\right)\left(e^{-\frac{\beta}{h^{2}} t m}-1\right)$

(14) 式より, $\eta_{m}=\eta_{0} \exp \left(\beta t_{m} / h^{2}\right)$ だから， 
$e^{-\frac{\beta}{h^{2}} t_{m}}=\frac{\eta_{0}}{\eta_{m}}$

である。それ故に，

$\int_{0}^{t_{m}} \frac{1}{\eta} d t=\frac{1}{\eta_{0}}\left(-\frac{h^{2}}{\beta}\right)\left(\frac{\eta_{0}}{\eta_{m}}-1\right)=\frac{h^{2}}{\beta}\left(\frac{1}{\eta_{0}}-\frac{1}{\eta_{m}}\right)$

となる。したがって，(5)式から下式が得られる。

$$
\begin{aligned}
& \ln \left(\frac{R_{P y a}}{R_{P y 0}}\right)=-\frac{\pi}{\lambda} \cdot f\left(\frac{2 \pi h}{\lambda}\right) \int_{0}^{t_{m}}\left(\frac{S}{\eta}\right) d t \\
&=-\frac{\pi S}{\lambda} \cdot f\left(\frac{2 \pi h}{\lambda}\right) \frac{h^{2}}{\beta}\left(\frac{1}{\eta_{0}}-\frac{1}{\eta_{m}}\right) \\
& R_{P y a}=R_{P y 0} \exp \left\{-\frac{\pi S}{\lambda} f\left(\frac{2 \pi h}{\lambda}\right) \frac{h^{2}}{\beta}\left(\frac{1}{\eta_{0}}-\frac{1}{\eta_{m}}\right)\right\}
\end{aligned}
$$

ところで，上式において更に弾性項を付与するため， $\int(1 / \eta) d t$ を Maxwell モデルを仮定した $1 / G+\int(1 / \eta) d t$ で置き換える。ここで，ポリエチレンの弾性率 $G$ は時間 (即ち，塗布速度，樹脂が同じときには，温度）の関数で あってもよいが，その依存性は $\eta$ に組み入れられている と解釈できるので，ここでは定数の平均弾性率と考えると， (18) 式は

$$
\begin{aligned}
& \ln \left(\frac{R_{P y a}}{R_{P y 0}}\right)=-\frac{\pi}{\lambda} \cdot f\left(\frac{2 \pi h}{\lambda}\right)\left\{\frac{S}{G}+\int_{0}^{t_{m}}\left(\frac{S}{\eta}\right) d t\right\} \\
& \quad=-\frac{\pi S}{\lambda} \cdot f\left(\frac{2 \pi h}{\lambda}\right) \frac{1}{G}-\frac{\pi S}{\lambda} f\left(\frac{2 \pi h}{\lambda}\right) \frac{h^{2}}{\beta}\left(\frac{1}{\eta_{0}}-\frac{1}{\eta_{m}}\right)
\end{aligned}
$$

となり， $\mathrm{RC}$ 紙の表面粗さ $R_{P y a}$ は

$$
\begin{array}{r}
R_{P y a}=R_{P y 0} \exp \left\{-\frac{\pi S}{\lambda} f\left(\frac{2 \pi h}{\lambda}\right) \frac{1}{G}\right\} \\
\times \exp \left\{-\frac{\pi S}{\lambda} f\left(\frac{2 \pi h}{\lambda}\right) \frac{h^{2}}{\beta}\left(\frac{1}{\eta_{0}}-\frac{1}{\eta_{m}}\right)\right\}
\end{array}
$$

となる.ここで, 平均弾性率は極めて高い值と仮定すると, 弾性項 $G_{c}$ は

$$
G_{c}=\exp \left\{-\frac{\pi S}{\lambda} \cdot f\left(\frac{2 \pi h}{\lambda}\right) \frac{1}{G}\right\} \cong 1
$$

となるので，塗布速度と樹脂が同じときの $\mathrm{RC}$ 紙の表面粗 さ $R_{P y a}$ は弾性項を考慮した $(20)$ 式で与えられる。また，塗 布速度が変わるときの弾性項の考慮は粘度項に補正項を付 与した (40)式 (4.5 節) によってモデル化した。

また，(20)式では塗布厚み $h$ が大きくなると波長 $\lambda$ で の $\mathrm{RC}$ 紙の表面粗さ $R_{P y a}$ が 0 になって現実にそぐわない. 即ち, 紙の表面粗さによらない樹脂本来の表面粗さ $R_{P y c}$ を 考慮する必要がある，従って，(20)式は次の形にするのが 妥当である. $\ln \left(\frac{R_{P y a}-R_{P y c}}{R_{P y 0}-R_{P y c}}\right)=-\frac{\pi S}{\lambda} \cdot f\left(\frac{2 \pi h}{\lambda}\right) \frac{h^{2}}{\beta}\left(\frac{1}{\eta_{0}}-\frac{1}{\eta_{m}}\right)$

また， $t_{m}$ 時間後の樹脂粘度 $\eta_{m}$ は極めて高い值であると 仮定すると， $1 / \eta_{m} \cong 0$ なので, $\mathrm{RC}$ 平坦化の予測式が下式 で与えられる.

$$
\ln \left(\frac{R_{P y a}-R_{P y c}}{R_{P y 0}-R_{P y c}}\right)=-\frac{\pi S h^{2}}{\lambda \beta \eta_{0}} \cdot f\left(\frac{2 \pi h}{\lambda}\right)
$$

$$
R_{P y a}=R_{P y c}+\left(R_{P y 0}-R_{P y c}\right) \exp \left[-\frac{\pi S h^{2}}{\lambda \beta \eta_{0}} \cdot f\left(\frac{2 \pi h}{\lambda}\right)\right]
$$

$\mathrm{RC}$ 紙の平坦化予測式 $(26)$ において,

$$
n=\exp \left[-\frac{\pi S h^{2}}{\lambda \beta \eta_{0}} \cdot f\left(\frac{2 \pi h}{\lambda}\right)\right]
$$

とおくと，(26)式は下式で表記される.

$$
\begin{aligned}
R_{P y a} & =\left(R_{P y 0}-R_{P y c}\right) n+R_{P y c} \\
& =n \cdot R_{P y 0}+(1-n) R_{P y c}
\end{aligned}
$$

\section{3 ピットについての考え}

ピットの発生について, T. F. Reed, H. E. Bair と R. G. Vadimsky ${ }^{6}$ はポリブタヂエンゴムを含有する射出成形 ABS プラスチック表面のピットの発生原因を成形時の残 留揮発物とポリブタヂエンゴムの収縮であるとしたが, RC 紙の製造時にその表面に出現するピットについては述べら れていない.また， $\mathrm{PE}$ 樹脂を 2 層に分割して逐次溶融押 し出しコーティングすることにより $\mathrm{RC}$ 紙のピットの発生 が低減できることが知られている7 が，その作用について は明らかでなかった。

われわれは， $\mathrm{RC}$ 紙の表面に発生するピットは，樹脂被 覆によっても基紙表面の凹凸，特に深い窪みは完全には埋 めきらなくて，依然として残留する凹凸，特に深い窪みの 容積が RC 紙表面に投影されるものであると考えた．基紙 表面の深い窪みの容積は，定量的な式で表記できないけれ ども，(29)式から理解されるように， $n \cdot R_{P y 0}$ は基紙を樹脂 で被覆したときの基紙表面に依然として残留する凹凸の表 面粗さを表すものと見なすことができる． $n \cdot R_{P y 0}$ の 3 乗は 相対容積と見なすことができるので，深い寉みが表面の凹 凸（容積）に比例すると仮定すると， $n \cdot R_{P y 0}$ は基紙表面の 完全には埋めきれない，依然として残留する深い窪みの表 面粗さを相対的に表すものと考えることができる。した がって，(26)式における要因の RC 紙表面の表面粗さ $R_{P y a}$ を小さくする方向のアクションによりピットの発生を少な くでき，逆に表面粗さ $R_{P y a}$ を大きくする方向のアクション によりピットの発生は多くなるものと考えられ，この観点 からの解析を行った. 


\section{3. 実験}

\section{$3.1 \mathrm{RC}$ 紙の作成}

\section{1 .1 表樹脂厚さの異なる $\mathrm{RC}$ 紙（その 1 ）}

中心面平均粗さ $S R_{0}$ が $1.30 \mu \mathrm{m}$ である基紙（厚さ 160 $\mu \mathrm{m})$ の一方の面 (裏面) にコロナ放電処理した後, $22 \mu \mathrm{m}$ の樹脂厚さで，ポリエチレン (密度 $0.956 \mathrm{~g} / \mathrm{cm}^{3}$, MFR 5.4 $\mathrm{g} / 10 \mathrm{~min}$ ）を溶融押し出しコーティングした. その後, 基 紙のもう一方の面 (表面) にコロナ放電処理した後, ポリ エチレン（密度 $0.920 \mathrm{~g} / \mathrm{cm}^{3}, M F R 4.5 \mathrm{~g} / 10 \mathrm{~min}$ )を，表 1 に記載の樹脂厚さで溶融押し出しコーティングし, 表面が 鏡面に加工された $\mathrm{RC}$ 紙を作成した. なお, 樹脂温度 $300^{\circ} \mathrm{C}$, 冷却温度 $30^{\circ} \mathrm{C}$, プレス張力 $S=3.6 \times 10^{6} \mathrm{~N} / \mathrm{m}$, 塗布速度 $180 \mathrm{~m} / \mathrm{min}$ で加工した。

\section{1 .2 表面粗さの異なる紙を基紙とする $\mathrm{RC}$ 紙}

表 3 に記載の中心面平均粗さ $S R_{0}$ である基紙の一方の面 (裏面) にコロナ放電処理した後, $22 \mu \mathrm{m}$ の樹脂厚さで, ポリエチレン（密度 $0.956 \mathrm{~g} / \mathrm{cm}^{3}$, MFR $5.4 \mathrm{~g} / 10 \mathrm{~min}$ ）を
Table 1 The thickness of $\mathrm{PE}$ resin layer and experimental and estimated SRa of RC paper

\begin{tabular}{c|c|c|c}
\hline $\begin{array}{c}\text { Thickness of } \\
\mathrm{PE}(\mu \mathrm{m})\end{array}$ & $\begin{array}{c}n \text { value } \\
\text { at } \lambda=15 \mu \mathrm{m}\end{array}$ & $\begin{array}{c}\text { Experimental } \\
S R_{a}(\mu \mathrm{m})\end{array}$ & $\begin{array}{c}\text { Estimated } \\
S R_{a}(\mu \mathrm{m}) \\
\text { at } \lambda=15 \mu \mathrm{m}\end{array}$ \\
\hline 33.5 & 0.0164 & 0.100 & 0.104 \\
\hline 30.7 & 0.0317 & 0.117 & 0.109 \\
\hline 24.6 & 0.109 & 0.141 & 0.137 \\
\hline 24.1 & 0.119 & 0.143 & 0.141 \\
\hline 18.2 & 0.297 & 0.214 & 0.205 \\
\hline 17.7 & 0.318 & 0.200 & 0.212 \\
\hline 12.2 & 0.581 & 0.278 & 0.307 \\
\hline 12.2 & 0.581 & 0.288 & 0.307 \\
\hline 10.2 & 0.688 & 0.387 & 0.345 \\
\hline 9.8 & 0.709 & 0.352 & 0.353 \\
\hline
\end{tabular}

Table 2 Results of the estimation of the surface roughness of RC paper

\begin{tabular}{c|c|c|c|c}
\hline $\begin{array}{c}\lambda \text { used to } \\
\text { estimate }(\mu \mathrm{m})\end{array}$ & $\begin{array}{c}\text { Regression } \\
\text { coeffient }\left(R^{2}\right)\end{array}$ & $\begin{array}{c}\text { Equation of } \\
\text { the regression line }\end{array}$ & $R_{P_{y 0}}(\mu \mathrm{m})$ & $S R_{c}(\mu \mathrm{m})$ \\
\hline 45 & 0.8763 & $S R_{a}=0.3578 \mathrm{~d}-0.0207$ & 0.3373 & -0.0207 \\
\hline 23.8 & 0.9447 & $S R_{a}=0.3347 \mathrm{~d}+0.0624$ & 0.3971 & 0.0624 \\
\hline 15 & 0.9641 & $S R_{a}=0.3596 \mathrm{~d}+0.0979$ & 0.4575 & 0.0979 \\
\hline 10 & 0.9628 & $S R_{a}=0.4136 \mathrm{~d}+0.1201$ & 0.5337 & 0.1201 \\
\hline 5 & 0.9101 & $S R_{a}=0.6863 \mathrm{~d}+0.1453$ & 0.8316 & 0.1453 \\
\hline 3.2 & 0.8496 & $S R_{a}=1.245 \mathrm{~d}+0.1568$ & 1.4018 & 0.1568 \\
\hline
\end{tabular}

Table 3 The analysis of the effect of the surface roughness of base paper on the surface roughness of RC paper and the generation of pits

\begin{tabular}{|c|c|c|c|c|c|}
\hline $\begin{array}{l}\text { The kind of } \\
\text { base paper }\end{array}$ & $\begin{array}{l}S R_{0}(\mu \mathrm{m}) \text { of } \\
\text { base paper }\end{array}$ & $\begin{array}{l}\text { The cube root of } \\
\text { the number of pits }\end{array}$ & $\begin{array}{l}n \cdot S R_{0} \text { value } \\
\text { at } \lambda=15 \mu \mathrm{m}\end{array}$ & $\begin{array}{l}\text { Experimental } \\
\qquad S R_{a}(\mu \mathrm{m})\end{array}$ & $\begin{array}{c}\text { Estimated } \\
\qquad R_{a}(\mu \mathrm{m}) \\
\text { at } \lambda=15 \mu \mathrm{m}\end{array}$ \\
\hline Cast paper 1 & 0.147 & 1 & 0.111 & 0.107 & 0.120 \\
\hline Cast paper 2 & 0.196 & 0 & 0.147 & 0.148 & 0.152 \\
\hline Cast paper 3 & 0.198 & 0 & 0.149 & 0.120 & 0.153 \\
\hline Cast paper 4 & 0.220 & 0 & 0.165 & 0.189 & 0.168 \\
\hline Cast paper 5 & 0.268 & 0 & 0.201 & 0.215 & 0.199 \\
\hline Coated paper 1 & 0.341 & 0 & 0.256 & 0.239 & 0.246 \\
\hline Coated paper 2 & 0.403 & 1 & 0.303 & 0.293 & 0.287 \\
\hline Coated paper 3 & 0.405 & 1.44 & 0.304 & 0.206 & 0.145 \\
\hline Coated paper 4 & 0.497 & 2.52 & 0.374 & 0.210 & 0.172 \\
\hline Coated paper 5 & 0.684 & 2.92 & 0.514 & 0.234 & 0.227 \\
\hline Base paper 1 & 1.356 & 6.55 & 1.019 & 0.391 & 0.427 \\
\hline Base paper 2 & 1.365 & 5.45 & 1.026 & 0.434 & 0.430 \\
\hline Base paper 3 & 1.930 & 9.45 & 1.451 & 0.596 & 0.598 \\
\hline
\end{tabular}

The surface roughness $S R_{a}$ of RC paper was estimated by the equation (A) in the case that the value of $n \cdot S R_{0}$ is less than 0.303 and the equation (B) in the case that the value of $n \cdot S R_{0}$ is more than 0.304 .

$S R_{a}=0.866 \times 0.752 \times n \cdot S R_{0}+0.0243 \cdots(\mathrm{A})$

$S R_{a}=0.395 \times 0.752 \times n \cdot S R_{0}+0.0243 \cdots(\mathrm{B})$

(The equation (A) and (B) are obtained from Fig.4.) 
溶融押し出しコーティングした。その後，基紙のもう一方 の面（表面）にコロナ放電処理した後， $9 \mu \mathrm{m}$ の塗布厚さ で，ポリエチレン(密度 $0.920 \mathrm{~g} / \mathrm{cm}^{3}$, MFR $4.5 \mathrm{~g} / 10 \mathrm{~min}$ ) を溶融押し出しコーティングし，表面が鏡面に加工された $\mathrm{RC}$ 紙を作成した.なお,加工条件は 3.1.1 節と同じである.

\subsection{3 表樹脂厚さの異なる $\mathrm{RC}$ 紙（その 2 )}

中心面平均粗さ $S R_{0}$ が $1.28 \mu \mathrm{m}$ である基紙（厚さ $160 \mu \mathrm{m})$ を用いて, 表 4 に記載の表樹脂厚さで溶融押し 出しコーティングすること以外は 3.1 .1 節と同じょうに $\mathrm{RC}$ 紙を作成した。

\subsection{4 表樹脂の塗布速度の異なる $\mathrm{RC}$ 紙}

中心面平均粗さ $S R_{0}$ が $1.30 \mu \mathrm{m}$ である基紙（厚さ $160 \mu \mathrm{m} ）$ の裏面を裏用ポリエチレンで被覆したものを用 いて，基紙のもう一方の面（表面）に表 4 に記載の塗布速 度と樹脂厚さで表用ポリエチレンを溶融押し出しコーティ ングすること以外は 3.1 .1 節と同じように $\mathrm{RC}$ 紙を作成し た。なお， $180 \mathrm{~m} / \mathrm{min}$ の塗布速度の $\mathrm{RC}$ 紙は 3.1 .3 節で作 成した樹脂厚さ $32.0 \mu \mathrm{m}$ のものを用いた.

\subsection{5 逐次 2 層 $\mathrm{RC}$ 紙}

中心面平均粗さ $S R_{0}$ が $1.30 \mu \mathrm{m}$ である基紙（厚さ $160 \mu \mathrm{m} ）$ の裏面を裏用ポリエチレンで被覆したものを用 いて，基紙のもう一方の面（表面）にコロナ放電処理した
後, 表用ポリエチレンを厚さ $15 \mu \mathrm{m}$ で溶融押し出しコー ティングして表面が鏡面に加工された RC 紙を作成した。 その後さらに, その $\mathrm{RC}$ 紙の表樹脂面に表用ポリエチレン を厚さ $15 \mu \mathrm{m}$ で溶融押し出しコーティングして表面が鏡 面に加工された逐次 2 層 $\mathrm{RC}$ 紙を作成した。なお，表樹脂 の加工は樹脂温度 $300^{\circ} \mathrm{C}$, 冷却温度 $30^{\circ} \mathrm{C}$, プレス張力 $S=$ $3.6 \times 10^{6} \mathrm{~N} / \mathrm{m}$, 塗布速度 $300 \mathrm{~m} / \mathrm{min}$ で行った. なお, 比 較用として単層 RC 紙は, 3.1.4 節で作成した塗布速度 300 $\mathrm{m} / \mathrm{min}$ ，樹脂厚さ $30 \mu \mathrm{m}$ のものを用いた.

\subsection{6 樹脂温度の異なる RC 紙}

中心面平均粗さ $S R_{0}$ が $1.30 \mu \mathrm{m}$ である基紙（厚さ $160 \mu \mathrm{m} ）$ の裏面を裏用ポリエチレンで被覆したものを用 いて，基紙のもう一方の面（表面）に表 6 に記載の樹脂温 度で表用ポリエチレンを溶融押し出しコーティングするこ と以外は 3.1.4 節の $250 \mathrm{~m} / \mathrm{min}$ のもと同じように RC 紙を作成した。なお，樹脂温度 $300^{\circ} \mathrm{C}$ の $\mathrm{RC}$ 紙は 3.1 .4 節 で作成したものを用いた。

\subsection{RC 紙の表面粗さの測定}

$\mathrm{RC}$ 紙の表面粗さとして，JIS-B 0601 に準拠して触針式 3 次元表面粗さ計を用いて抄紙方向の下式で定義される中 心面平均粗さ $S R_{a}$ を測定した。

Table 4 The analysis at $\lambda=15 \mu \mathrm{m}$ of the effect of the coating speed of the resin layer on the generation of pits

\begin{tabular}{c|c|c|c|c|c|c|c|c|c}
\hline $\begin{array}{c}\text { Coating } \\
\text { speed }: v \\
(\mathrm{~m} / \mathrm{min})\end{array}$ & $\begin{array}{c}\text { Thickness } \\
\text { of the resin } \\
\text { layer }: \mathrm{h}(\mu \mathrm{m})\end{array}$ & $\begin{array}{c}S R_{0}(\mu \mathrm{m}) \\
\text { of the base } \\
\text { paper }\end{array}$ & $P$ value & $B$ value & $B_{c}$ value & $n$ value & $n_{A}$ value & $\begin{array}{c}\text { Experimental } \\
S R_{a}(\mu \mathrm{m})\end{array}$ & $\begin{array}{c}\text { Estimated } \\
S R_{a}(\mu \mathrm{m})\end{array}$ \\
\hline 180 & 32.0 & 1.28 & 0.91 & 1.00 & 1.00 & 0.0235 & 0.0235 & 0.107 & 0.107 \\
\hline 200 & 30.0 & 1.30 & 1.82 & 0.550 & 0.632 & 0.0371 & 0.125 & 0.109 & 0.109 \\
\hline 250 & 30.0 & 1.30 & 3.00 & 0.369 & 0.359 & 0.0371 & 0.306 & 0.113 & 0.112 \\
\hline 300 & 30.0 & 1.30 & 4.02 & 0.269 & 0.264 & 0.0371 & 0.419 & 0.114 & 0.114 \\
\hline
\end{tabular}

The viscosity $\eta_{0}$ of the resin and the $\beta$ value at the temperature $300{ }^{\circ} \mathrm{C}$ are $427(\mathrm{~Pa} \cdot \mathrm{s})$ and $0.482\left(\mathrm{~m}^{2} / \mathrm{s}\right)$ respectively.

The $P$ value is the cube root of the number of pits.

The $B$ value, the $B_{C}$ value, the $n$ value and the $n_{A}$ value were calculated by the equation (39), (41), (27) and (40), respectively.

Table 5 The analysis at $\lambda=15 \mu \mathrm{m}$ of the effect of the tandem coating of the resin layer on the generation of pits

\begin{tabular}{c|c|c|c|c|c|c|c}
\hline \multicolumn{2}{c|}{ PC paper type } & $\begin{array}{c}S R_{0} \text { of the } \\
\text { base }(\mu \mathrm{m})\end{array}$ & $\begin{array}{c}\text { Thickness of } \\
\text { the resin }: h(\mu \mathrm{m})\end{array}$ & $n_{A}$ value & $n_{A} \cdot S R_{0}$ & $\begin{array}{c}\text { Experimental } \\
P \text { value }\end{array}$ & $\begin{array}{c}\text { Estimated } \\
P \text { value }\end{array}$ \\
\hline \multirow{2}{*}{ Double type } & Lower layer & 1.30 & 15.0 & 0.744 & 0.962 & 7.01 & 6.93 \\
\cline { 2 - 8 } & Upper layer & 0.215 & 15.0 & 0.744 & 0.160 & 1.44 & 1.47 \\
\hline \multicolumn{2}{c|}{ Single type } & 1.30 & 30.0 & 0.306 & 0.398 & 3.00 & 3.09 \\
\hline
\end{tabular}

The viscosity $\eta_{0}$ of the resin and the $\beta$ value at the temperature $300^{\circ} \mathrm{C}$ are $427(\mathrm{~Pa} \cdot \mathrm{s})$ and $0.482\left(\mathrm{~m}^{2} / \mathrm{s}\right)$ respectively.

The $n_{A}$ value and the estimated $P$ value were calculated by the equation (40) and (39) respectively using the value of $B_{C}=0.359$.

Table 6 The analysis at $\lambda=15 \mu \mathrm{m}$ of the effect of the temperature of the resin on the surface roughness of the RC paper and the generation of pits.

\begin{tabular}{c|c|c|c|c|c|c|c|c}
\hline $\begin{array}{c}\text { Temperature } \\
\text { of the resin }\left({ }^{\circ} \mathrm{C}\right)\end{array}$ & $\begin{array}{c}\text { Viscosity of the } \\
\text { resin }: \eta_{0}(\mathrm{~Pa} \cdot \mathrm{s})\end{array}$ & $\beta$ value & $\frac{\pi S \times 10^{-8}}{\lambda \beta \eta_{0}}$ & $n$ value & $n_{A}$ value & $n_{A} \cdot S R_{0}$ & $\begin{array}{c}\text { Experimental } \\
P \text { value }\end{array}$ & $\begin{array}{c}\text { Estimated } \\
P \text { value }\end{array}$ \\
\hline 300 & 427 & 0.482 & 36.616 & 0.0371 & 0.306 & 0.398 & 3.00 & 3.09 \\
\hline 310 & 359 & 0.500 & 41.983 & 0.0229 & 0.258 & 0.335 & 2.67 & 2.66 \\
\hline 320 & 302 & 0.517 & 48.266 & 0.0130 & 0.210 & 0.273 & 2.15 & 2.24 \\
\hline
\end{tabular}

The $n_{A}$ value and the estimated $P$ value were calculated by the equation (40) and (39) respectively using the value of $B_{C}=0.359$. 


$$
S R_{a}=\frac{1}{S_{a}} \int_{0}^{W x} \int_{0}^{W y}|f(x, y)| d x, d y
$$

式(30)において, $W x$ は試料面域の $x$ 軸方向（抄紙方向） の長さを表し， $W y$ は試料面域の $y$ 軸方向（抄紙方向と垂 直な方向）の長さを表し， $S_{a}$ は試料面域の面積を表す. 触針式 3 次元表面粗さ計及び 3 次元粗さ解析装置を用い, カットオフ值 $0.8 \mathrm{~mm}, W x=20 \mathrm{~mm}, W y=8 \mathrm{~mm}$, 従って $S_{a}=160 \mathrm{~mm}^{2}$ の条件で求めた. なお， $x$ 軸方向のデー夕処 理としてはサンプリングを 500 点行い, $y$ 軸方向の走査と しては, 16 線以上行った.

\section{3 ピットの計測}

三次元表面粗さ計を用いて, MD（基紙の抄紙方向） 20 $\mathrm{mm}, \mathrm{CD}$ 方向 $8 \mathrm{~mm}$ の範囲につき $\mathrm{MD}$ 方向に 16 ライン トレースする.レコーダーに出力した粗さのうち $1 \mu \mathrm{m}$ 以 上の下方向のシャープな突起をピットとして, 16 ライン の総数をピット数とした.

三次元表面粗さ計の作動条件は以下の通りである.

測定長： $20.8 \mathrm{~mm}$ ，テーブルピッチ：0.5 mm,

記録ピッチ：5.0 mm, H. Magnification : 10,

V. Magnification : 2000, カットオフ : $0.8 \mathrm{~mm}$.

\section{4 樹脂の粘度測定}

表面粗さの理論值計算のための低密度ポリエチレン（以 下 LDPE と言う）樹脂の初期粘度 $\eta_{0}$ と粘度の温度依存性 係数 $\beta$ を決定するために，コーンプレート粘度計で周波 数 $1 \mathrm{rad} / \mathrm{s}$ で 3.1.1 節に記載の LDPE 樹脂の粘度の温度依 存性を測定した。

\section{4. 結果と考察}

\section{1 初期粘度 $\eta_{0}$ と $\beta$ 值の決定}

実験に用いた LDPE 樹脂の温度変化に伴う粘度測定の 結果，粘度の温度依存性を表す下式を得た。

$$
\ln \mu\left(N \cdot s / m^{2}\right)=-0.0173 T(K)+15.971
$$

いま，この LDPE 樹脂の粘度の温度依存性と本実験での LDPE 樹脂組成物の粘度の温度依存性は等しいと仮定し, $\mathrm{PE}$ 樹脂組成物の $300^{\circ} \mathrm{C}$ の初期粘度 $\eta_{0}=427\left(\mathrm{~N} \cdot \mathrm{s} / \mathrm{m}^{2}\right)$, 粘 度の温度依存性係数 $b=0.0173(1 / \mathrm{K})$ とした。

また，文献 值 ${ }^{8} よ り \mathrm{LDPE} の 126-200^{\circ} \mathrm{C}$ の $k=0.223$ $(\mathrm{J} / \mathrm{m} \cdot \mathrm{s} \cdot \mathrm{K}), T_{0}=300^{\circ} \mathrm{C}$ のとき $T_{f}=30^{\circ} \mathrm{C}$ なので, $T_{0}-T_{f}=$ $270(\mathrm{~K})$, 文献值 ${ }^{9)} よ り \mathrm{LDPE} の 150^{\circ} \mathrm{C}$ の $\rho=0.782 \times 10^{-3}$ $\left(\mathrm{kg} / \mathrm{m}^{3}\right)$, 文献值 ${ }^{10)}$ より LDPEの $120^{\circ} \mathrm{C} よ り$ 高い温度での $C=2.765 \times 10^{3}(\mathrm{~J} / \mathrm{kg} \cdot \mathrm{K})$ の各係数值を本実験での LDPE 樹脂組成物の各係数值に等しいと仮定し，各係数值を(13) 式に代入して, $T_{0}=300^{\circ} \mathrm{C}$ のとき $\beta=0.482\left(\mathrm{~m}^{2} / \mathrm{s}\right)$ を得た.

\section{$4.2 \mathrm{RC}$ 紙表面粗さに及ぼす樹脂厚さの効果}

樹脂厚さが $\mathrm{RC}$ 紙の表面粗さに及ぼす効果を(26) 式, 即 ち(28) 式により解析を行った。作成した $\mathrm{RC}$ 紙の表面粗さ の測定結果を表 1 に示す.

表 1 から, 樹脂厚さが厚いほど $\mathrm{RC}$ 紙の表面粗さ $S R_{a}$ が 小さく, 逆に樹脂厚さが薄いほど $\mathrm{RC}$ 紙の表面粗さが大き く, 樹脂厚さが $\mathrm{RC}$ 紙の表面粗さと密接に相関しているこ とがわかる.
(28) 式における $R_{P y a}, R_{P y 0}$ および $R_{P y c}$ はそれぞれ解析さ れる波長 $\lambda$ での $\mathrm{RC}$ 紙, 基紙および樹脂固有の表面粗さ （以下樹脂表面粗さという）を表すが， $R_{P y a}$ と $R_{P y c}$ を $S R_{a}$ と $S R_{c}$ にそれぞれ読み替えると,

$$
S R_{a}=\left(R_{P y 0}-S R_{c}\right) n+S R_{c}
$$

が得られる.ここで, $S R_{a}$ と $S R_{c}$ は $0.8 \mathrm{~mm}$ カットオフで の多数の波長の表面粗さで構成されている，従って，(32） 式は, 多数の波長の粗さで構成される $\mathrm{RC}$ 紙の表面粗さ $S R_{a}$ および樹脂表面粗さ $S R_{c}$ と基紙の特定波長の粗さ $R_{P y 0}$ との対応を表す式である. それ故に, それらの対応性がよ いということは，基紙のその波長の粗さが $S R_{a}$ を支配して おり, その波長が $\mathrm{RC}$ 紙の表面粗さの主波長であると解釈 される。

(32) 式から理解されるように, $n$ 值に対して $S R_{a}$ をプ ロットし, その近似直線の勾配 $=R_{P y 0}-S R_{c}$, 切片 $=S R_{c}$ で あるので， $R_{P y 0}$ と $S R_{c}$ を容易に求めることができる. 各波 長での $n$ 值に対する $\mathrm{RC}$ 紙の中心面表面粗さ $S R_{a}$ の対応を 検討し, その結果を表 2 に示す. また, 波長 $\lambda=15 \mu \mathrm{m}$ での計算例を図 3 に示す.

表 2 の結果から，波長 $10 \mu \mathrm{m} \sim 23.8 \mu \mathrm{m}$ において重相 関係数 $\left(R^{2}\right)$ が 0.94 を越えており, $\mathrm{RC}$ 紙の $S R_{a}$ は, そ れらの波長における基紙の粗さ $R_{P y 0}$ と $(32)$ 式により密接に 相関していることがわかる，いま，ある範囲内での基紙の 表面粗さについては，比例関係にあると仮定すると，

$$
\left.R_{P y 0}=K_{1} \cdot S R_{0} \quad （ 33 ） （ こ こ に, K_{1} \text { : 換算係数. }\right)
$$

であり，(32)式より $\mathrm{RC}$ 紙の表面粗さ $S R_{a}$ を表す中心面平 均粗さ基準の計算式が下式で与えられる.

$$
S R_{a}=\left(K_{1} \cdot S R_{0}-S R_{c}\right) n+S R_{c}
$$

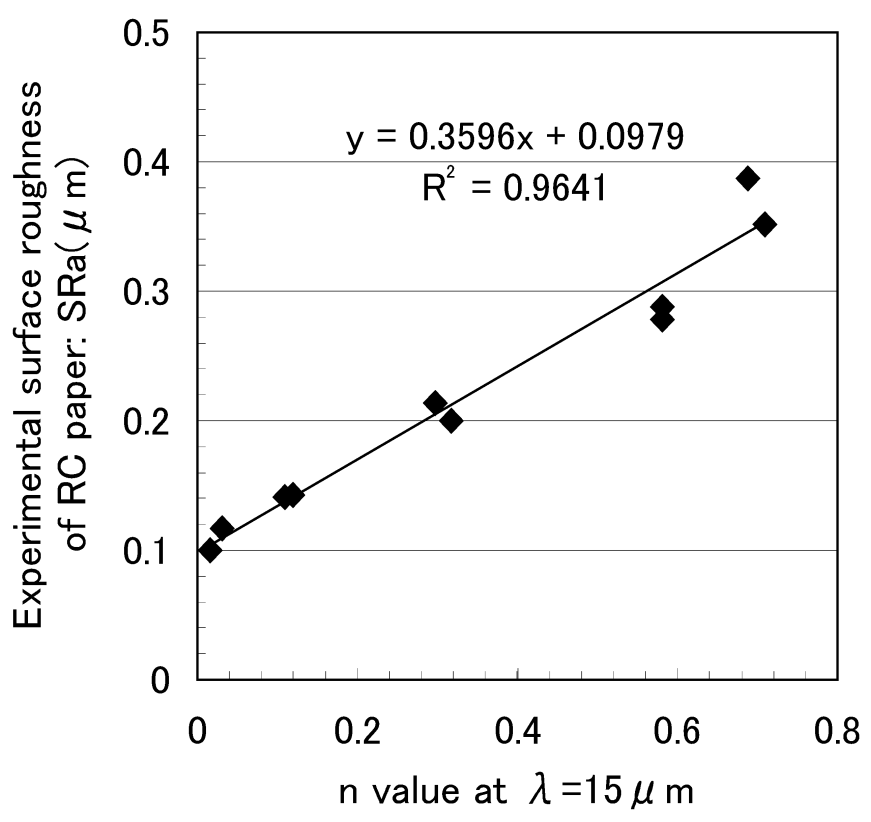

Fig. 3 Plots of $S R_{a}$ versus n value 


$$
\begin{gathered}
=\left(K_{1} \cdot S R_{0}-S R_{c}\right) \exp \left[-\frac{\pi S h^{2}}{\lambda \beta \eta_{0}} f\left(\frac{2 \pi h}{\lambda}\right)\right]+S R_{c} \\
\text { (ここに, } \lambda=15 \mu \mathrm{m})
\end{gathered}
$$

樹脂厚さの異なる $\mathrm{RC}$ 紙の (35) 式で見積もった表面粗さ $S R_{a}$ の計算值を表 1 に示すが, 実験値と計算値の重相関係 数 $\left(R^{2}\right)$ は 0.964 であり, 良い一致を示した.

このことから，(35)式，即ち (26) 式の $\mathrm{RC}$ 紙の平坦化予 測式により, 実駼值と合致する $\mathrm{RC}$ 紙の $S R_{a}$ を求めること ができ, 粗さの主波長を決定できるので, 本報の平坦化の 予測式は妥当で有用であることが理解できる.

\section{$4.3 \mathrm{RC}$ 紙表面粗さとピットに及ぼす基紙表面粗さの 効果}

基紙の表面粗さが $\mathrm{RC}$ 紙の表面粗さに及ぼす効果を(26) 式により解析を行い, 合わせてピットの発生個数を計測し てその発生要因を検討した。作成した $\mathrm{RC}$ 紙の表面粗さと ピットの測定結果を表 3 に示す.

表 3 から，基紙の表面粗さ $S R_{0}$ が小さいほど $\mathrm{RC}$ 紙の表 面粗さ $S R_{a}$ が小さくピットの発生も少なく, 逆に基紙の表 面粗さが大きいほど RC 紙の表面粗さが大きくピットの発 生も多く, 基紙の表面粗さが $\mathrm{RC}$ 紙の表面粗さおよびピッ 卜の発生と密接に相関していることがわかる.

$n$ 值を用いて表記する $\mathrm{RC}$ 紙の平坦化予測式(32)を変形 すると，

$$
S R_{a}=n R_{P 0}+(1-n) S R_{0}
$$

が得られる.（36) 式は, 多数の波長の粗さで構成される $\mathrm{RC}$ 紙の表面粗さ $S R_{a}$ と樹脂表面粗さ $S R_{c}$ と基紙の特定波長の 粗さ $R_{B_{0} 0}$ との対応を表す式である.

基紙の表面粗さが $\mathrm{RC}$ 紙の表面粗さ $S R_{a}$ に及ぼす影響を (36) 式で解析するには, $R_{P_{0} 0}$ を $S R_{a}$ 基準の粗さに変換する 必要がある。いま, ある範囲内での基紙の表面粗さについ ては，比例関係にあると仮定すると，

$$
\begin{gathered}
R_{P y_{0}}=K_{n} \cdot S R_{0} \\
\text { (ここに, } \left.K_{n}: \text { 換算係数. }\right)
\end{gathered}
$$

であり，(36)式は下式となる.

$$
S R_{a}=K_{n} n \cdot S R_{0}+(1-n) S R_{c}
$$

(38) 式から理解されるように, $\left(n \cdot S R_{0}\right)$ 值に対して $S R_{a}$ をプロットすると, その近似直線の勾配 $=K_{n}$, 切片 $=(1-$ n) $S R_{c}$ であるので， $K_{n}$ と $S R_{c}$ を容易に求めることができる。 このとき基紙の表面粗さが幅広い範囲にわたっているので 基紙の表面粗さを平均的に 2 つ層別して考えると， $\mathrm{RC}$ 紙の表面粗さ $S R_{a}$ を支配している基紙の主波長 $\lambda$ 依存割 合が異なる，即ち近似直線の勾配が異なる 2 つの理論式が 与えられる. 各波長での $\left(n \cdot S R_{0}\right)$ 值に対する $\mathrm{RC}$ 紙の中心 面表面粗さ $S R_{a}$ の対応を検討した，その際樹脂表面粗さを 表す近似直線の切片は一定であると考えられるので, 4.1 節で求めた切片 $\left(S R_{c}=0.0979 \mu \mathrm{m}\right)$ にフィッティングし た。その結果，基紙表面粗さの異なる $\mathrm{RC}$ 紙の (38) 式で見

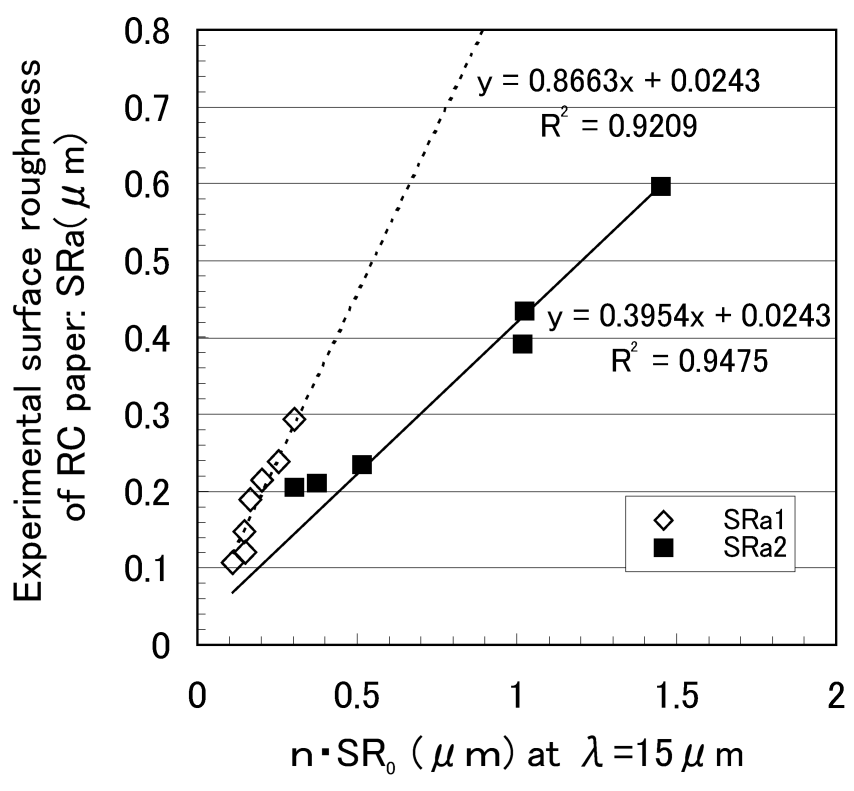

Fig. 4 Plots of $S R_{a}$ of $\mathrm{RC}$ paper resin-coated on base papers having various roughness versus $n \cdot S R_{0}$

積もった表面粗さ $S R_{a}$ の波長 $\lambda=15 \sim 100 \mu \mathrm{m}$ での計算值 と実験值の重相関係数 $\left(R^{2}\right)$ は 0.921 以上であり, ほほ 一致する結果を示した。波長 $\lambda=15 \mu \mathrm{m}$ （このとき $n=$

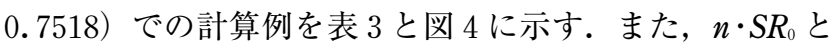
ピットの発生数の 3 乗根の対応を図 5 に示す.

図 4 より, 基紙表面粗さの異なる $\mathrm{RC}$ 紙の表面粗さ $S R_{a}$ を表す $S R_{a}$ 基準の計算式が $\lambda=15 \mu \mathrm{m}$ での(38)式で与え られることがわかる.また, 図 5 より $n \cdot S R_{0}$ とピットの発 生数の 3 乗根はほぼ対応することがわかる. 言い換えれば, $n \cdot S R_{0}$ の 3 乗とピットの発生数がほぼ対応することを意味 する. 2.3 節で述べたように, $n \cdot S R_{0}$ は基紙表面の完全に は埋めきれない，依然として残留する梁い寉みの表面粗さ を相対的に表すものと考えることができ，また $n \cdot S R_{0}$ の 3 乗は相対容積と見なすことができるので，ピットの発生数 が $n \cdot S R_{0}$ の 3 乗にほほ対応するということは，ピットは, 基紙を樹脂で被覆しても依然として残留する深い寉みの容 積が RC 紙表面に投影されたものであると考えられる.

以上のことから，(38) 式，即ち (26) 式の $\mathrm{RC}$ 紙の平坦化 予測式により，実験值とほぼ合致する $\mathrm{RC}$ 紙の $S R_{a}$ を求め ることができ，粗さの主波長を決定でき，また実験值とほ ぼ合致するピットの発生数を予測できるので, 本報の RC 紙平坦化のモデルは妥当で有用であることが理解できる.

\section{4 ピットに及ぼす樹脂厚さの効果}

樹脂厚さがピットの発生に及ぼす効果を解析するために, $n \cdot S R_{0}$ 值とピットの発生数の 3 乗根の対応を調へ，その結 果を図 6 に示す.

図 6 から, 樹脂厚さが厚いほどピットの発生が少なく, 逆に樹脂厚さが薄いほどピットの発生が多く, 樹脂厚さが ピットの発生と密接に相関していることがわかる。また, $n \cdot S R_{0}$ 值とピットの発生数の 3 乗根はよく対応すること, 即ち $n \cdot S R_{0}$ 值の 3 乗とピットの発生数がよく対応するこ とわかり，4.2節で議論したようにピットが基紙を樹脂で 被覆しても依然として残留する深い窪みの容積が RC 紙表 面に投影されたものであることを示す結果を得た. 


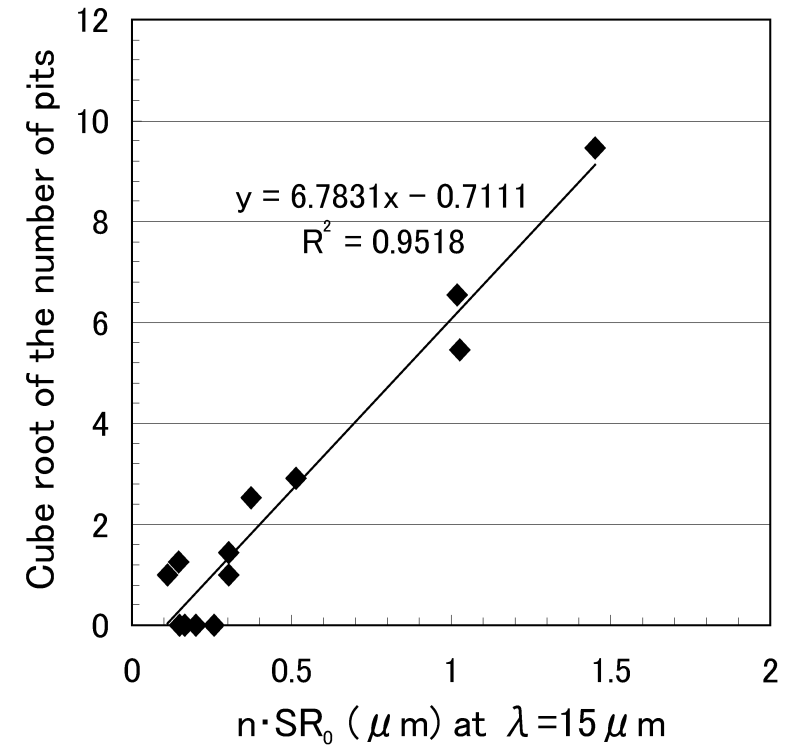

Fig. 5 Plots of cube root of the number of pits versus $n \cdot S R_{0}$

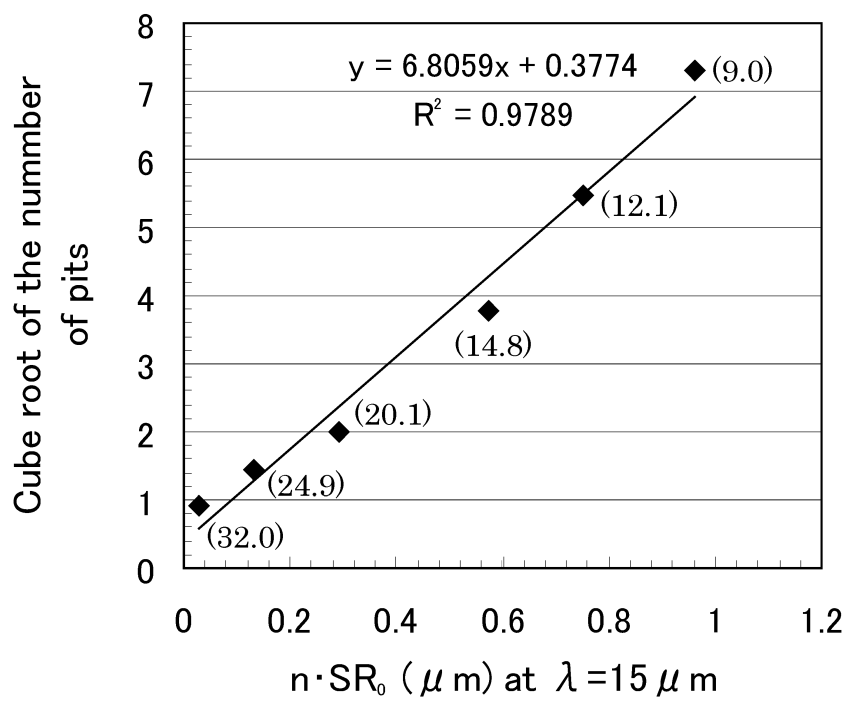

(The parenthesized numerical value represents the thickness of $\operatorname{PE}(\mu \mathrm{m}))$

Fig. 6 The effect of the thickness of the front resin layer of $\mathrm{RC}$ paper on the generation of pits

\section{5 ピットに及ぼす樹脂の塗布速度の効果}

表用ポリエチレンを 180，200，250および $300 \mathrm{~m} / \mathrm{min}$ で溶融押し出しコーティングした時のピットの発生状況と そのときの各係数值を表 4 に示す $(180 \mathrm{~m} / \mathrm{min}$ のデータ は 4.4 節のデータを用いた).

表 4 より, 樹脂の塗布速度を早くすると, ピットの発生 数が相当多くなることがわかる. しかし, ピットの増加の 割合は，これまでのようにして求めた $n$ 值を用いて $n \cdot S R_{a}$ 值とピットの発生数の 3 乗根（以下 $P$ 值という）の対応 を調べると，4.4 節または 4.5 節で得られた結果と異なる ことがわかる.

この理由として, 樹脂がプレス張力で引っ張られて平坦 化するときに, 樹脂の塗布速度が早くなって引っ張り速度 勾配が大きくなるにつれて低密度ポリエチレンの弾性挙動 が顕著になるため ${ }^{11)}$, 樹脂が基紙の深い窪みを埋めること

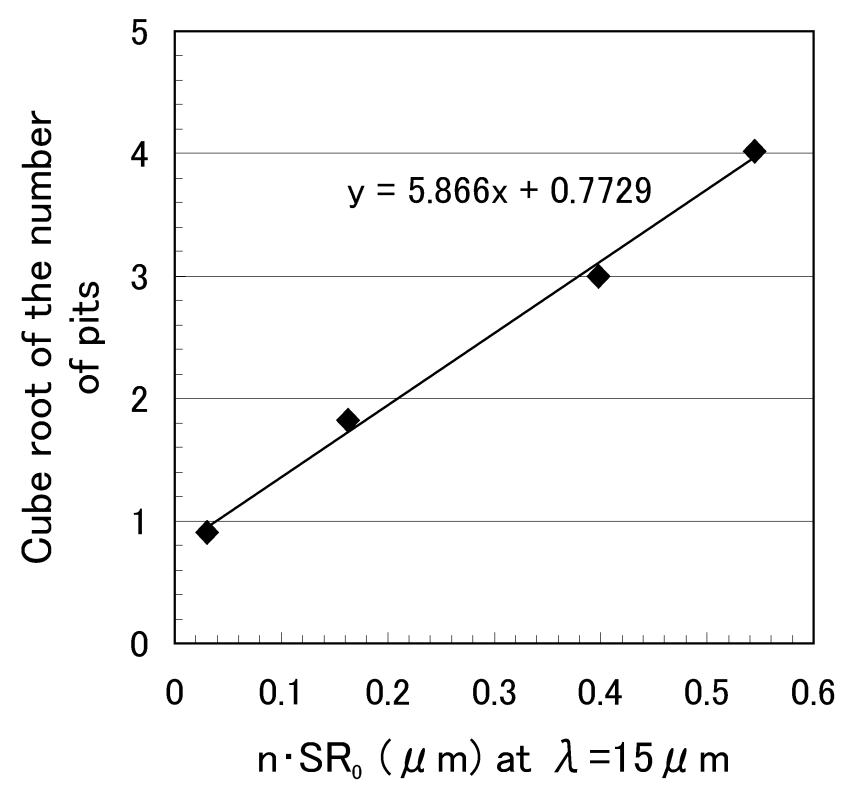

Fig. 7 The analysis of the effect of the coating speed of the resin layer on the generation of pits

が困難となり，その結果ピットが多数発生するものと考え た.この弾性挙動を補正するために, 塗布速度に応じて RC 紙表面に発生するピット数と基紙を樹脂で被覆しても依然 として残留する凹凸の容積との対応関係を用いて見かけの $n$ 值 $\left(n_{A}\right.$ 值 $)$ を見積もった. $P$ 值と $n \cdot S R_{0}$ 值との関係の 基本式として, 図 6 で得られた下式を用いた。このとき, (22) 式の弾性項の塗布速度依存性は, 粘度項に補正係数 $(B$ 值）を付与した (40) 式によって考慮したので, 弾性項 $G_{c} \cong$ 1 と考えた.

$$
\begin{gathered}
P=6.81 n_{A} \cdot S R_{0}+0.377 \\
n_{A}=\exp \left\{-f\left(\frac{2 \pi h}{\lambda}\right) h^{2} \cdot \frac{\pi S}{\lambda \beta \eta_{0}} \times B\right\} \\
\left(こ こ に, B=\text { 補正係数, } \lambda=15 \mu \mathrm{m}, \mathrm{S}=3.6 \times 10^{-6} \mathrm{~N} / \mathrm{m}\right)
\end{gathered}
$$

(39) 式で得られた $B$ 值と塗布速度 $v$ との対応をあらため て求めて下式を得た.

$$
\ln B=1.94\left(v / v_{0}\right)^{-2}-2.03
$$

(39) 式で求めた $B$ 值，(41) 式で求めた補正した $B$ 值（ $B_{C}$ 值), (29) 式で求めた $n$ 值および $B_{C}$ 值を用いて (40) 式で 求めた見かけの $n$ 值 $\left(n_{A}\right.$ 值) の結果を表 4 に示す. また, $n_{A} \cdot S R_{0}$ 值とピットの発生数の 3 乗根 ( $P$ 值) の対応結果 を図 7 に示す.

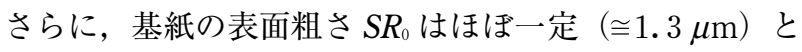
見なせるので， $n_{A}$ 值と $\mathrm{RC}$ 紙の表面粗さ $S R_{a}$ との対応を求 めて下式を得た.

$$
S R_{a}(\mu \mathrm{m})=0.0193 n_{A}(\text { dimension less })+0.106
$$

(42) 式で求めた $\mathrm{RC}$ 紙の表面粗さ $S R_{a}$ の計算值も合わせて 
表 4 に示す.

以上のように，見かけの $n$ 值を導入して樹脂塗布速度 の高速化に伴うポリエチレンの弾性効果を定量化すること により，ピットの発生状況をこれまでの議論と同様に解釈 できることがわかる. 即ち, $n_{A} \cdot S R_{0}$ 值とピットの発生数 の 3 乗根はよく対応すること, 即ち $n_{A} \cdot S R_{0}$ 值の 3 乗とピッ トの発生数がよく対応することになり，4.2 節で議論した ようにピットが基紙を樹脂で被覆しても依然として残留す る深い寉みの容積が $\mathrm{RC}$ 紙表面に投影されたものであるこ とを示す結果が得られる。 また, 樹脂塗布速度の高速化に 伴い $\mathrm{RC}$ 紙の表面粗さがやや大きくなることがわかった. これらのことは, ポリエチレンの弾性効果により基紙の垂 直方向に法線応力が生じ，そのためプレスロールによる実 効プレス圧力が相応に低下し, 結果的にプレス張力が相応 に小さくなるためであると考えられる.

\section{6 ピットに及ぼす樹脂の逐次 2 層塗布の効果}

表用ポリエチレンを単層で溶融押し出しコーティングし た時と単層の $1 / 2$ の塗布厚さで逐次 2 層で溶融押し出し コーティングした時のピットの発生状況とそのときの各倸 数值を表 5 に示す (単層のデー夕は 4.5 節の塗布速度 250 $\mathrm{m} / \mathrm{min}$ のデー夕を用いた)． $n_{A}$ 值は 4.5 節で得られた 250 $\mathrm{m} / \mathrm{min}$ での $B_{C}$ 值 $=0.359$ を用いて $(40)$ 式で求めた.

表 5 より, 同一の樹脂塗布厚さの場合には, 逐次 2 層叙 布した $\mathrm{RC}$ 紙の方が, 単層塗布した $\mathrm{RC}$ 紙に比して, 顕著 にピットの発生が少なくなることがわかる．この理由は, 逐次 2 層塗布の場合には $n_{A}$ 值は大きくなるにもかかわら ず 2 度目に塗布する基材の表面粗さ $S R_{0}$ が顕著に小さくな るために, $n_{A} \cdot S R_{0}$ が単層叙布した場合に比してかなり小 さくなるためであることがよく理解できる.

\section{7 樹脂温度がピットに及ぼす効果}

表用ポリエチレンの温度を 300,310 および $320^{\circ} \mathrm{C}$ で溶 融押し出しコーティングして $\mathrm{RC}$ 紙の作成した時のピット の発生状況とそのときの各係数值を表 6 に示す $\left(300^{\circ} \mathrm{C}\right.$ の デー夕は 4.4 節の $250 \mathrm{~m} / \mathrm{min}$ デー夕を用いた).

表 6 より，(39)式で見積もったピットの発生数と実験值 は良い対応性を示し, 本報の $\mathrm{RC}$ 紙平坦化モデルに基づく ピットの予測モデルが妥当であることがわかる.

\section{5. と め}

基紙にポリエチレン樹脂を被覆した樹脂被覆紙（ $\mathrm{RC}$ 紙） の平滑性に関して, $\mathrm{RC}$ 紙の表面粗さとピット（または梨 地）と呼称される $\mathrm{RC}$ 紙の表面に発生する鋭い䆶みの解析 を行った。まず，塗液のコーティングに扔けるレベリング の理論を発展させて $\mathrm{RC}$ 紙の表面粗さを表す $\mathrm{RC}$ 紙平坦化 の予測式を構築し，その予測式による $\mathrm{RC}$ 紙の表面粗さの
計算値と実験值の比較を行った結果良い一致が見られ，構 築した RC 紙平坦化の予測式が妥当であることがわかった.

また， $\mathrm{RC}$ 紙平坦化予測式から得られる基紙を樹脂で被 覆しても依然として残留する深い寉みの相対容積の指標に 基づいて構築したピットの予測モデルによるピットの計算 值と実験值の比較を行った結果良い一致が見られ，構築し たピットの予測モデルが妥当であり，またピットは樹脂で 被覆しても依然として残留する深い窪みの容積が RC 紙表 面に投影されたものであることがわかった，その際，樹脂 の弾性挙動を補正する相対容積の指標を用いることにより， 幅広く応用できるピットの予測モデルが構築できた。

以上から，本報の $\mathrm{RC}$ 紙平坦化予測式およびピットの予 測モデルにより, 画像材料用支持体である樹脂被覆紙の表 面粗さとピットを的確に予測できるようになり, この評価, 計測方法は樹脂被覆紙の設計に有効であると考えられる.

\section{謝辞}

本研究の発表を許可して頂いた三菱製紙株式会社に謝意 を表します。また，本研究について有意義な助言を頂いた 日本ポリケム株式会社の世利卓也氏に謝意を表します.

\section{参 考 文 献}

1) Parson, T. F., Gray, G. G. and Crawford, I. H. : Journal of Applied Photographic Engineering, 5, 110 (Spring 1979)

2 ) Adelstein, P. Z. and Burnham, J. M.: "Physical Properties Imaging Materials", second ed., by C. Noel Proundfoot, 368 (1997), IS\& T

3 ) Orchard, S. E. : Appl. Sci., Sect. A, 11, 451 (1963)

4）高橋幸伯, 町田 進: 基礎材料力学, 184 (1999), 培 風館

5 ) McKelvey, J. M., 伊藤勝彦訳：高分子加工工学, “POLYMER PROCESSING", 37 (1976), 現代工学社

6 ) Reed, T. F., Bair, H. E. and Vadimsky, R. G.: ACS Polymer Preprint, 14 (2), 1074 (1973)

7 ) 特開昭 59-198451 号（富士写真フィルム）

8 ) Baird, D. G. and Collias, D. I. : Polymer Processing Principles and Design, 318 (1998), John Wiley and Sons, Inc., New York

9 ) Baird, D. G. and Collias, D. I. : Polymer Processing Principles and Design, 104 (1998), John Wiley and Sons, Inc., New York

10) VanNess, R. T.: Tappi, 47 (11), 725 (1964)

11）荒木敏雄：プラスチックス，41 (8)，89(2002) 